\title{
Recovery of Vegetation Structure and Species Diversity after Shifting Cultivation in Northwestern Vietnam, with Special Reference to Commercially Valuable Tree Species
}

\author{
Do Van Tran, ${ }^{1,2}$ Akira Osawa, ${ }^{1}$ and Thang Toan Nguyen $^{2}$ \\ ${ }^{1}$ Lab of Forest Utilization, Graduate School of Agriculture, Kyoto University, Kyoto 606-8502, Japan \\ ${ }^{2}$ Silviculture Research Division, Forest Science Institute of Vietnam, Tu Liem, Ha Noi, Vietnam \\ Correspondence should be addressed to Do Van Tran, dotranvan@hotmail.com
}

Received 1 July 2011; Accepted 19 July 2011

Academic Editors: S. F. Ferrari and D. Yemane Ghebrehiwet

Copyright ( 2011 Do Van Tran et al. This is an open access article distributed under the Creative Commons Attribution License, which permits unrestricted use, distribution, and reproduction in any medium, provided the original work is properly cited.

\begin{abstract}
A fallow stand (FS) in northwestern Vietnam that was created by shifting cultivation 32 years earlier had $43 \%$ of the species number, $72 \%$ of the stem density, and $53 \%$ of the basal area when compared with nearby old-growth forest (OGF); however, the values for commercial species were lower at 35\%,67\%, and 26\%, respectively. In terms of species diversity, the Shannon index of OGF (3.4) was significantly higher than that of FS (2.6), while the differences were not significant in terms of Evenness and species-size class distribution. Both FS and OGF had similar patterns of stem diameter frequency distribution but the diameters were more diverse in OGF compared to FS according to the Shannon index. Fallow stand was characterized by only 2 canopy layers (lower than $10 \mathrm{~m}$ and 10-20 m) and was simpler in vertical structure than that of OGF which included an additional upper canopy layer higher than $20 \mathrm{~m}$. Our results indicate that increasing stem density of commercial species is necessary and can be realized by artificial seeding, planting seedlings, and/or natural regeneration from remaining mother trees in the fields.
\end{abstract}

\section{Introduction}

Agricultural encroachment by shifting cultivation (swidden or slash-and-burn agriculture) has been an important topic in the debate on tropical deforestation. Despite rapid economic development in many tropical countries, millions of people, particularly in the humid tropics, still practice shifting cultivation [1]. Shifting cultivators are often seen as the primary agents of deforestation in developing countries $[2,3]$. In Vietnam, an area of 3.5 million ha is used for shifting cultivation by 50 ethnic minorities [4].

Regeneration of secondary forest is an essential part of shifting cultivation [5]. After field abandonment, the secondary forest develops naturally [6-8]. Research in tropical rain forests has produced reasonable insights into the patterns of secondary succession $[9,10]$, while that in tropical dry forest is lagging behind [11]. Successional studies indicate that secondary forests can serve as carbon sinks [12], and enhance regional biodiversity, environmental services, and forest-based economies $[3,13,14]$. Forests at different stages of succession differ in total biomass, net primary production, and species composition $[8,12,15]$. The rate of recovery in species diversity is higher in the humid and moist tropics, whereas regeneration to restore the structure of a mature forest is faster in the dry tropical forest [16]. However, species diversity and composition in the secondary forests usually remain distinctly different from that of primary forests $[17,18]$. It may take from decades to centuries for secondary forest $[9,19]$ to recover completely, depending on previous land use [20] and the intensity of previous disturbances $[21,22]$.

Studies of succession after shifting cultivation in tropical regions have also indicated that the diversity of woody species gradually increases with fallow age $[7,8,23,24]$. It is also likely that the frequent use of fire to prepare the fields for following year's crops favors grasses, which probably limit 
seedling establishment due to competition [25]. Differences in shifting cultivation practices of various ethnic groups in Thailand [15], Laos [26], and Vietnam [27] have also resulted in differences in the recovery rate of secondary forest. Therefore, understanding secondary vegetation development is fundamental to achieve restoration and management goals for such successional areas [28].

Since launching The Sedentary Farming and Resettlement Program by the Vietnamese Government in the 1970s for regions of northwestern Vietnam, shifting cultivation has declined, leading to increase in fallow areas, which have partly been converted to timber-producing forests. However, little attention has been given to the study of forest recovery after abandonment of shifting cultivation. Some of the important questions to be answered are recovery of species diversity, especially for commercial tree species, and forest structure. In this study, we evaluated species composition, diversity, and structure of a 32-year-old fallow stand (FS) recovered after shifting cultivation and compared it to old-growth forest (OGF) in northwestern Vietnam. The following hypotheses were tested.

(i) Species composition and richness of the 32-year-old FS are lower than that of the OGF; we plan to test this hypothesis with respect to the commercially valuable timber species in particular.

(ii) Forest structure in terms of diameter frequency distribution and canopy height is simpler in FS than in OGF.

\section{Materials and Methods}

2.1. Site Description. The study was conducted in northwestern Vietnam at $21^{\circ} 15^{\prime} \mathrm{N}-103^{\circ} 24^{\prime} \mathrm{E}$. The elevation of the area ranged from 600 to $1824 \mathrm{~m}$ above sea level. In this area, the vegetation is characterized by evergreen broad-leaved forest [29]. The climate is warm and moist. The mean annual rainfall is $1277 \mathrm{~mm}$, in which $80 \%$ falls in the summer (from May to July) and the rest in the winter (from November to March). The annual relative humidity is $80 \%$, mean monthly temperature ranges from 21 to $23^{\circ} \mathrm{C}$ in summer and 12 to $16^{\circ} \mathrm{C}$ in winter [30]. The dominant soil types are ferralic acrisols, acidic soils with low base saturation and poor nutrient content. Humic acrisols and rhodic ferralsols are also found occasionally [31]. The soil in 5-10-year-old fallow stands was generally acidic with a low $\mathrm{pH}$ of $4.3-4.8$ and had a clay ratio of $18-23 \%$, humus content of $4.5-5.2 \%$, nitrogen concentration of $0.15-0.2 \%$, and $\mathrm{P}_{2} \mathrm{O}_{5}$ concentration of $0.8-$ $1.1 \mathrm{mg} / 100 \mathrm{~g}$ [32].

There are two main ethnic minorities living in the field site region: Thai and H'Mong. The Thai, consist of $15 \%$ of the total population, and live in lower elevations $(<800 \mathrm{~m})$ where they mainly cultivate paddy rice. The H'Mong ( $80 \%$ of the population) live in mountainous areas of middle and upper elevations $(>800 \mathrm{~m})$, and mainly practice pioneer shifting cultivation $[15,33]$. In the pioneer shifting cultivation, most tree stumps are uprooted after slashing and burning of the natural forest. The land is abandoned only when the crops cannot grow well or their yield reduces to $20-30 \%$ of that of the first year, due to nutrient depletion in the soil [32]. H'Mong people slash and burn natural forest from January to April. They grow upland rice in the first year, and maize or cassava in the next two to five years. During the cultivation period, the plots are weeded once or twice per year. After each year's harvest, the land is prepared for the following year by the same method of slash and burn techniques. Generally, the land is abandoned after the fifth or sixth year for natural regeneration.

A small part of forest land in the research area is covered by old-growth forest (OGF), which is mostly located on mountain tops or high elevation zones or along streams. These areas are reserved by custom for water supply of the paddy rice grown at lower elevations and for daily water use. Disturbance of OGF is prohibited by law, but there has been some unauthorized logging of high value trees (e.g., Fokienia hodginsii, Terminaria myriocarpa). However, the disturbance levels in OGF are small compared to other regions of northwestern Vietnam.

2.2. Data Collection. A tree census was conducted 5 in a $32-$ year-old fallow stand (FS) recovered after pioneer shifting cultivation and in an old-growth forest (OGF). Age of the FS was identified by interviewing village patriarchs and was confirmed by using growth rings taken with tree increment borer. The eight largest trees, which varied from $20 \mathrm{~cm}$ to $54 \mathrm{~cm}$ in diameter at breast height (one of Lindera sinensis (Lauraceae), one of Alniphyllum eberhardtii (Styracaceae), two of Castanopsis cerebrina (Fagaceae), two of Schima wallichii (Theaceae), and two of Eriolaena candollei (Malvaceae)) were cored $20 \mathrm{~cm}$ above ground level in the FS plot. Meanwhile, age of OGF was 250 years old [8].

Two main plots of one hectare $(100 \mathrm{~m} \times 100 \mathrm{~m})$ each were used: one for FS and the other for OGF. The plot for the thirty-two-year-old fallow stand was located at $1420 \mathrm{~m}$ elevation; that of the OGF was located at $1517 \mathrm{~m}$. The two plots were about $150 \mathrm{~m}$ apart from each other, such distance was selected since it is typical for current research site, and those two plots were assumed to constitute the same original forest type and thus suitable for a chronosequence study. Each 1-ha plot was further divided into 16 sub-plots of $25 \mathrm{~m} \times 25 \mathrm{~m}$ each. All individuals with diameter at breast height $(\mathrm{dbh}) \geq 5 \mathrm{~cm}$ (referred to as tree stratum) were identified to species $[34,35]$, measured for total height $(H)$ and dbh by girth, and recorded separately for these 16 subplots. In each subplot, one quadrat of $10 \mathrm{~m} \times 10 \mathrm{~m}$ was randomly established for identifying species and measuring $H$ and dbh of all individuals with $\mathrm{dbh}<5 \mathrm{~cm}$ and $H \geq 2 \mathrm{~m}$ (referred to as the sapling stratum). In each quadrat, five subquadrats of $3 \mathrm{~m} \times 3 \mathrm{~m}$ each were randomly established for identifying species and measuring $H$ of individuals in the seedling stratum $(H<2 \mathrm{~m})$. Traditional uses of each species were determined by interviewing six local people. Species were classified as commercial or noncommercial based on traditional knowledge of the local people. Species, of which wood is easily sold in the local market at a high price, were identified as commercial trees. In general, those species usually had a high wood density/durability [36]. 


\subsection{Data Analysis}

2.3.1. Species Diversity and Composition. Diversity indices [37] including Shannon's index $\left(H^{\prime}\right)$ and Evenness $\left(J^{\prime}\right)$ were used to evaluate species diversity.

In the present analysis, "species-size class" diversity is also used. Suppose that stand A contains $S$ species with a total of $N$ individuals and individuals of each species are focused in one size lass (e.g., only in the tree stratum), while stand $\mathrm{B}$ has the same $S$ species and $N$ individuals, but individuals of each species are distributed among all size classes (e.g., in seedling, sapling, and tree strata). Then, stand B should have a greater species-size class diversity than stand A. Species-size class diversity $\left(H_{\mathrm{ss}}^{\prime}\right)$ and species-size class Evenness $\left(J_{\mathrm{ss}}^{\prime}\right)$ were, then, calculated as (1) and (2), respectively,

$$
\begin{gathered}
H_{\mathrm{ss}}^{\prime}=-\sum_{J=1}^{\mathrm{sc}} \sum_{i=1}^{s} p_{j i} * \ln p_{j i}, \\
J_{\mathrm{ss}}^{\prime}=\frac{H_{\mathrm{ss}}^{\prime}}{H_{\mathrm{ss}-\max }},
\end{gathered}
$$

where, $p_{j i}=n_{j i} / N, H_{s s-\max }=\operatorname{Ln}(S * s c)$, sc is number of size classes (in this study, three size classes were used as seedlings for $H<2 \mathrm{~m}$, saplings for $H \geq 2 \mathrm{~m}$ and $\mathrm{dbh}<5 \mathrm{~cm}$, and trees for $\mathrm{dbh} \geq 5 \mathrm{~cm}), n_{j i}$ is number of individuals of the $i$ th species in size class $j(j=1-3), N$ is total number of individuals of all species, and $S$ is total number of species in the surveyed plots. The $J_{s s}^{\prime}$ becomes the maximum value of unity if all species have the same number of individuals and individuals of each species are distributed equally among all size classes.

A one hectare survey plot for the 32-year-old fallow stand (FS) or that for the old-growth forest (OGF) may not represent all species present in that stand. Because a complete census is feasible only under a few special situations, it is necessary to estimate species richness by sampling the target species assemblage. There are a number of equations for species estimation; however, Chao [38] provides the least biased estimate and accurate estimate of true species richness for small number of samples [39]. Species accumulation curve based on the number of samples (sub-plots) was calculated by (3) [38] with 95\% confidence intervals, using the analytical formulas of Colwell et al. [40]

$$
S_{e}=S_{o}+\left(\frac{m-1}{m}\right)\left(\frac{Q_{1}\left(Q_{1}-1\right)}{2\left(Q_{2}+1\right)}\right),
$$

in which $S_{e}$ is number of species estimated, $S_{o}$ is number of species observed in samples, $m$ is total number of samples, $Q_{1}$ is number of species present in only one sample, and $Q_{2}$ is number of species present in exactly two samples.

2.3.2. Properties and Shape of dbh-Distribution. The Shannon index [37] was used to evaluate the diameter diversity, in which relative frequency of stems in the diameter class $i$ (pi) and the number of diameter classes $(n)$ were used for calculation. The cumulative basal area-distribution was described as a Lorenz curve [41] to examine the location of size inequality among the basal area distributions. Lorenz curves were calculated based on stem populations versus basal area in cumulative percentages of plant member in ascending order of their size at 10, 20, 30, 40, 50, 60, 70, 80, and $90 \%$.

The inequality of basal area-distributions was described by using the Gini coefficient [41], which was calculated based on the arithmetic average of the absolute mean values of the differences between all pairs of stem diameters:

$$
G=\frac{\sum_{i=1}^{n} \sum_{j=1}^{n}\left|\mathrm{dbh}_{i}-\mathrm{dbh}_{j}\right|}{2 n^{2} \mathrm{dbh}_{m}},
$$

where $n$ is number of stems measured in a stand and $\mathrm{dbh}_{m}$ is the mean diameter. $G$ has a minimum value of 0 where all stems have equal diameter and a theoretical maximum of 1 where all stems except one have a value of 0 .

The relationship between stem height and diameter was fitted following equation (5) $[15,42]$

$$
\frac{1}{H}=\frac{1}{H_{\max }}+\frac{1}{a * \mathrm{dbh}^{b}},
$$

in which $H$ is stem height in $\mathrm{m}, H_{\max }$ is maximum asymptotic stem height (maximum height of $30 \mathrm{~m}$ was used in this study, this is the height of the tallest trees in the OGF), dbh is stem diameter at breast height in $\mathrm{cm}$, and $a$ and $b$ are constants. The coefficients $a$ and $b$ were estimated by fitting a straight line on the log-transformed values of the inverse of $1 / H-1 / H_{\max }$ against $\log \left(a * \mathrm{dbh}^{b}\right)$. Equation (5) was adopted because both FS and OGF appeared to show the asymptotic maximum values of tree height for a range of stem diameters.

\section{Results}

3.1. Species Diversity and Composition. In total, we found 32 tree species belonging to 30 genera and 20 families in the 32year-old fallow stand (FS), while 74 tree species belonging to 57 genera and 35 families were found in the old-growth forest (OGF). All species found in FS were also found in OGF. Individuals of all species in FS were present in the seedling stratum. This decreased to 29 species in the sapling stratum, and to 26 species in the tree stratum. Conversely, in the OGF sixty-one species were present in the seedling stratum, 65 in the sapling stratum, and 69 in the tree stratum. There was a total density of 5,550 stems ha $^{-1}(3,820$ seedlings, 1,190 saplings, and 540 trees) in FS and 7,570 stems ha ${ }^{-1}(6,180$ seedlings, 940 saplings, and 550 trees) in OGF. The FS had recovered $53.2 \%$ of the total basal area of the OGF (Table 1).

A mean of $11.5( \pm 1.4)$ species per $25 \mathrm{~m} \times 25 \mathrm{~m}$ plot was found in FS, which was significantly lower $(P<0.001)$ than the mean of $18.6( \pm 3.6)$ in OGF (Table 1$)$. Significant differences were also found in the species number between FS and OGF for tree $(9.2 \pm 1.9$ and $15.7 \pm 2.7$, resp., $P<0.001)$ and seedling $(11.2 \pm 1.0$ and $8.8 \pm 1.1$, resp. $P<0.001)$ strata; however, it was not different in the sapling stratum $(10.3 \pm 1.6$ in FS and $11.1 \pm 1.9$ in OGF $)$. In terms of the variation in mean stem densities between FS and OGF, the difference was significant for the sapling stratum $(1,193 \pm$ 


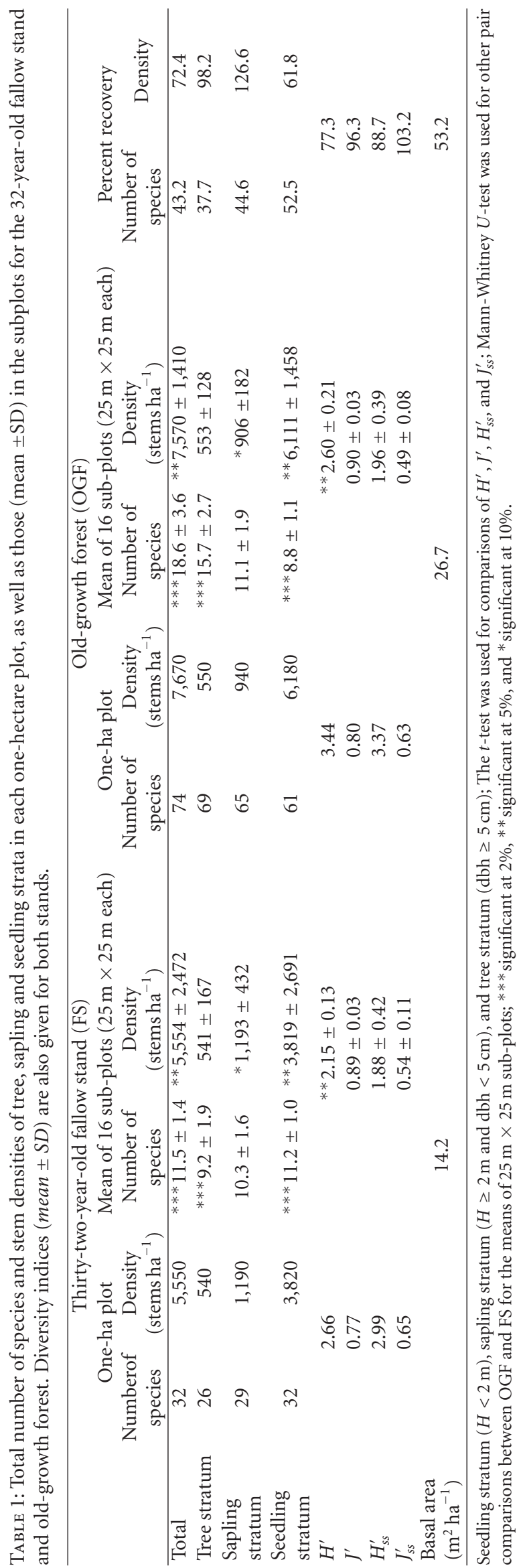




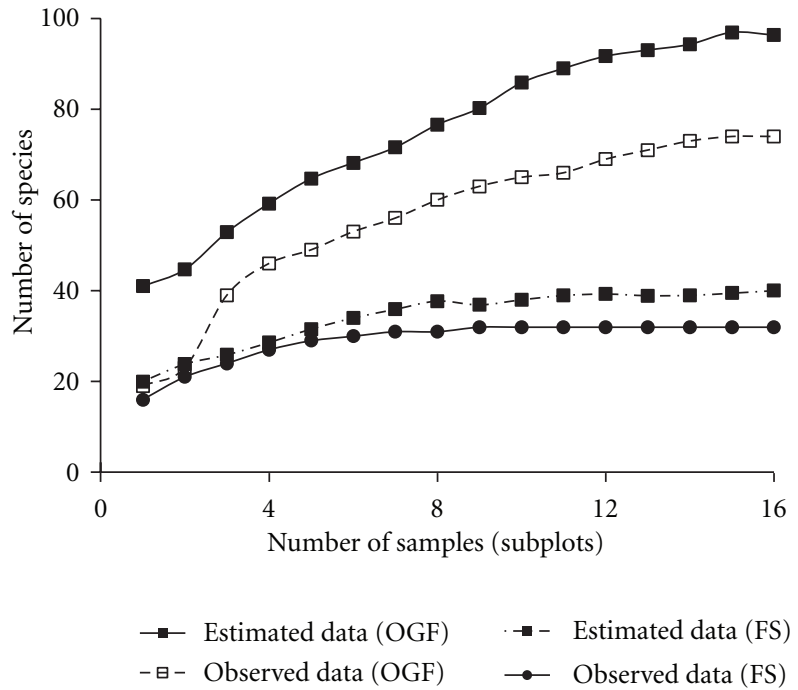

Figure 1: Chao's species number estimation by number of surveyed plots. Percentage of overestimate $=($ number of estimated species number of observed species)/number of observed species $* 100$. This was calculated for corresponding number of samples (subplots). OGF is old-growth forest and FS is a 32-year-old fallow stand.

432 stems ha $^{-1}$ and $906 \pm 182$ stems ha $^{-1}$, resp. $\left.P=0.039\right)$ and for the seedling stratum $\left(3,819 \pm 2,691\right.$ stems ha ${ }^{-1}$ and $6,111 \pm 1,458$ stems ha ${ }^{-1}$, resp. $\left.P=0.021\right)$; meanwhile it was not significant for the tree stratum $\left(541 \pm 167\right.$ stems ha $^{-1}$ and $553 \pm 128$ stems ha ${ }^{-1}$, resp.) (Table 1$)$.

Species diversity index $\left(H^{\prime}\right)$ showed a significant difference $(P<0.001)$ between FS $(2.15 \pm 0.13)$ and OGF $(2.60$ $\pm 0.21)$; however, it was not different in terms of Evenness $(0.89 \pm 0.03$ and $0.90 \pm 0.03$, resp. $)$. Meanwhile, there were no significant differences between FS and OGF (Table 1) in terms of species-size class diversity $(1.88 \pm 0.42$ and $1.96 \pm$ 0.39 , resp.) and species-size class Evenness (0.54 \pm 0.11 and $0.49 \pm 0.08$, resp.).

Fifty-six and 30 species were used by the local people for traditional uses (see the appendix). The traditional uses include collection of plant organs as food (fruit, leaf, etc.), medicine (headache, stomachache, etc.), construction material (housing, etc.), and other uses (resin, tannin, ornamental, etc.). The species that can be used for multiple purposes were numbered 18 in OGF and 12 in FS (see the appendix).

There were large differences between the observed species number and estimated species number in both FS and OGF. The number of species estimated for OGF was 96.3 $( \pm 12.8)$, which was $130 \%$ of the observed species number (74 species). The estimated number of species for FS was 40.0 ( \pm 6$), 125 \%$ of the observed species number (32 species) (Figure 1). For small sample numbers (less than 8 sub-plots), the discrepancy between the estimated and observed species number was large and varied from 6 to $25 \%$ for FS and from 28 to $95 \%$ for OGF. Increasing number of samples led to stability of the estimated species number for both FS and OGF (Figure 1).

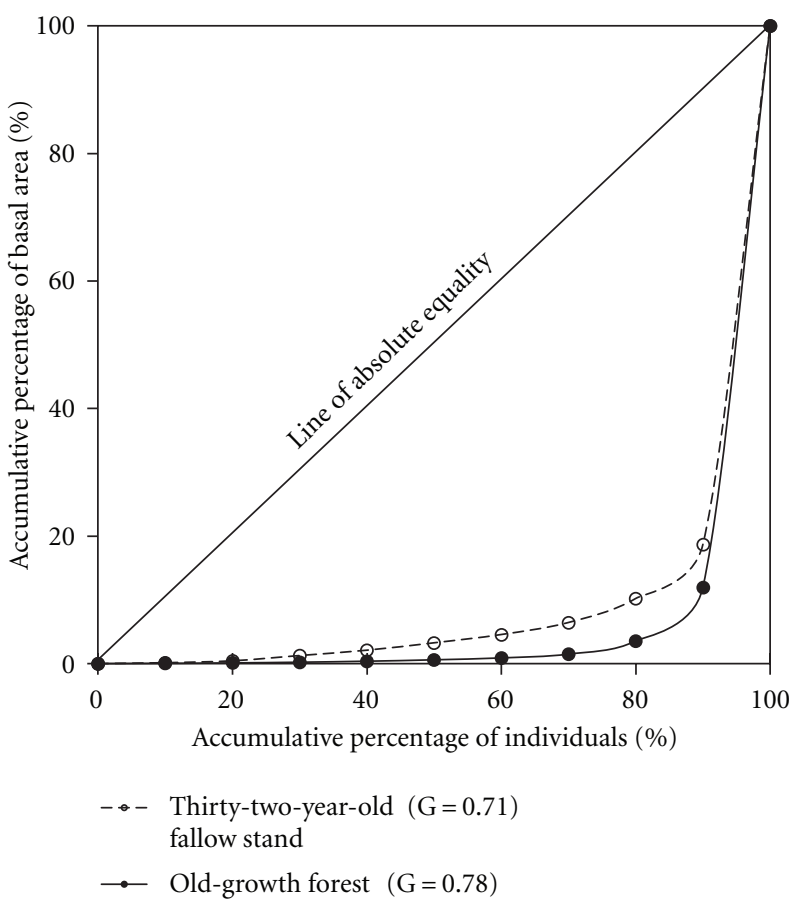

Figure 2: The Lorenz curve as applied to size inequalities in plant populations. The horizontal axis is the cumulative percentage of individuals in a stand, summed from the smallest to the largest. The area between the curve and line of absolute equality expressed as a proportion of the area under the diagonal is called the Gini coefficient (G, [41]).

3.2. Forest Structure. Growth rings of Schima wallichii indicated that this tree was 32 years old. Meanwhile, it was 19, 21, 25, and 26 years old for trees of Eriolaena candollei, Alniphyllum eberhardtii, Lindera sinensis, and Castanopsis cerebrina, respectively. The age of the fallow stand was assigned 32 years, since the age of the sampled individuals was clustered in one group, and Schima wallichii generally regenerates immediately after land abandonment from shifting cultivation [43].

The shapes of the Lorenz curves were similar between 32-year-old fallow stand (FS) and old-growth forest (OGF). Both showed very slow basal area accumulation at the first $90 \%$ of population accumulation. In the 32-year-old fallow stand, accumulation of basal area was $0.14,1.26,3.27,6.45$, and $18.6 \%$ for $10,30,50,70$, and $90 \%$ of population accumulation in ascending order, respectively. On the other hand, accumulation of basal area was 0.04, 0.22, 0.60, 1.49, and $11.9 \%$ for $10,30,50,70$, and $90 \%$ of population accumulation in OGF. The value of the Gini coefficient was also similar between FS (0.71) and OGF (0.78) (Figure 2).

Table 2 shows that there were 12 and 34 commercial species found in FS and OGF, respectively (see the appendix). Commercial species accounted for $39.2 \%\left(5.6 \mathrm{~m}^{2} \mathrm{ha}^{-1}\right)$ total basal area in FS and $80.1 \%\left(21.4 \mathrm{~m}^{2} \mathrm{ha}^{-1}\right)$ in OGF. Both FS and OGF had low percentages of total stem densities of commercial species, $36.6 \%$ and $37.6 \%$, respectively. The percent recovery was quite high for stem density $(67.2 \%)$. However, it was low for species number $(35.3 \%)$, especially for basal area with only $26.2 \%$. 
TABLE 2: Commercial species presence in 32-year-old fallow stand and in old-growth forest.

\begin{tabular}{|c|c|c|c|c|c|}
\hline & \multicolumn{2}{|c|}{ Thirty-two-year-old fallow stand (FS) } & \multicolumn{2}{|c|}{ Old-growth forest (OGF) } & \multirow[b]{2}{*}{$\begin{array}{c}{ }^{\text {a Percent recovery }} \\
\text { in FS }\end{array}$} \\
\hline & $\begin{array}{c}\text { Commercial } \\
\text { species }\end{array}$ & $\begin{array}{l}\text { Proportion to all } \\
\text { species }(\%)\end{array}$ & $\begin{array}{c}\text { Commercial } \\
\text { species }\end{array}$ & $\begin{array}{l}\text { Proportion to all } \\
\text { species }(\%)\end{array}$ & \\
\hline Species number & 12 & 37.5 & 34 & 45.9 & 35.3 \\
\hline $\begin{array}{l}\text { Tree stratum } \\
\left(\text { stems ha }{ }^{-1}\right)\end{array}$ & 217 & 40.2 & 347 & 63.1 & 62.5 \\
\hline $\begin{array}{l}\text { Sapling stratum } \\
\left(\text { stems ha }{ }^{-1}\right)\end{array}$ & 270 & 23.2 & 320 & 34.9 & 84.4 \\
\hline $\begin{array}{l}\text { Seedling stratum } \\
\left(\text { stems } \mathrm{ha}^{-1}\right)\end{array}$ & 1,420 & 37.3 & 2,170 & 35.1 & 65.4 \\
\hline $\begin{array}{l}\text { Total density } \\
\left(\text { stems ha }{ }^{-1}\right)\end{array}$ & 1,907 & 36.6 & 2,837 & 37.6 & 67.2 \\
\hline $\begin{array}{l}\text { Basal area } \\
\left(\mathrm{m}^{2} \mathrm{ha}^{-1}\right)\end{array}$ & 5.6 & 39.2 & 21.4 & 80.1 & 26.2 \\
\hline
\end{tabular}

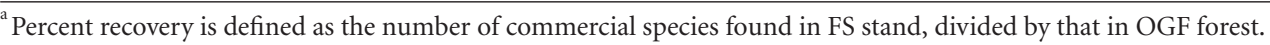

Both FS and OGF had a skewed bell-shaped distribution of stem diameters with greater representation of the small diameter classes; however, the positions of the peaks were different between the stands (Figure 3). Stem diameter of the 32-year-old fallow stand (FS) peaked at the diameter class of $4-6 \mathrm{~cm}$ with a relative frequency of $29.1 \%$, while that of OGF peaked at the diameter class of $2-4 \mathrm{~cm}$ with a frequency of $41.0 \%$. Diameter of the trees in FS was as large as 50-52 cm, while that of OGF extended to the $>72 \mathrm{~cm}$ class with the largest stem diameter of $96.8 \mathrm{~cm}$. In terms of the diameter diversity index (Ddi), there was a significant difference $(P=0.03)$ between FS (1.91) and OGF (2.18) for the pooled data of all species. The same pattern of dbh was found for the commercial species and the difference of diameter diversity was also significant $(P=0.01)$ between FS and OGD (Figure 3(b)).

Seventy six percent of stems were smaller than the $10 \mathrm{~cm}$ diameter in OGF; the proportion increased to $88.6 \%$ for stems $<20 \mathrm{~cm} \mathrm{dbh}$. Those proportions were $85.6 \%$ and $99.3 \%$, respectively, in FS. There were only $0.7 \%$ of stems in the diameter classes greater than $20 \mathrm{~cm}$ in FS; this proportion was higher (11.4\%) in OGF (Figures $3(\mathrm{a})$ and 4 ). The maximum height of the forest canopy was $30 \mathrm{~m}$ for both FS and OGF. However, structure of the forest canopy was simpler in FS: $85.6 \%$ of stem density was found in the stratum below $10 \mathrm{~m}$ and $14.1 \%$ in the $10-20$ meter height layer. Only five individuals $(0.3 \%)$ had tree heights greater than $20 \mathrm{~m}$ in FS (Figure 4(a)). Meanwhile, canopy structure was more complex in OGF: $73.6 \%$ of stem density was present in the layer below $10 \mathrm{~m}, 20.1 \%$ was in the $10-20$ meter height layer, and $6.3 \%$ in the layer higher than $20 \mathrm{~m}$ (Figure 4(b)).

\section{Discussion}

4.1. Characteristics of Species Diversity and Composition. By using chronosequence sampling of fallow stands, Tran et al. [8] concluded that fallow stands developing after pioneer sifting cultivation require 60 years to return to the same number of species and $80 \%$ aboveground biomass of the surrounding old-growth forest in northwestern Vietnam. The percent recovery of a 32-year-old fallow stand (FS) in the present study was $43.2 \%$ in species number and $53.2 \%$ in total basal area (Table 1). If the recovery rate of the fallow stand is stable in the following years, the fallow stand in the present study may require 74 years for recovery of the species number and 60 years for basal area. While Wangpakapattanawong et al. [44] found that it required only 6 years for a fallow stand in western Thailand to fully recover its species number, a rotational shifting cultivation was applied there, where much of the soil seed bank and surviving roots and stumps were available for regeneration after only one year of cropping.

Recovery rate of the species number in the tree stratum $(37.7 \%)$ was lower than that of the sapling stratum $(44.6 \%)$ and seedling stratum (52.5\%) (Table 1). This is a common pattern since seedlings and saplings of slow-growing species require many years to be recruited into the tree stratum. Contrary to the species number, stem density recovered faster (Table 1): percent recovery was $98.2 \%$ for the tree stratum and $126.6 \%$ for the sapling stratum. The contribution of early successional species (i.e., Schima wallichii, Camelia tsaii; [43]) was important during this stage of recovery. Lebrija-Trejos et al. [7] found that stem density increased gradually in the first 10 years after land abandonment in very dry tropical deciduous forest in southern Mexico, after which it became stable. Meanwhile, stem density tended to decrease over the years in fallow stands of mixed-deciduous forest in northwestern Laos [45] and in tropical rain forest in northwestern Vietnam [8]. These studies indicate the complexity of the recovery process of secondary forest in the tropics. To recover to a state comparable to old-growth forest (OGF) in terms of stem density, the fallow stand in the present study must recruit more stems, especially in the seedling stratum (current percent recovery was 61.8\%). Facilitating natural seed rain from the surrounding oldgrowth forests may be necessary to accomplish this.

The number of species increased from tree to sapling and seedling strata in FS while this pattern was reversed in OGF. This may be caused by the fact that seedlings and 


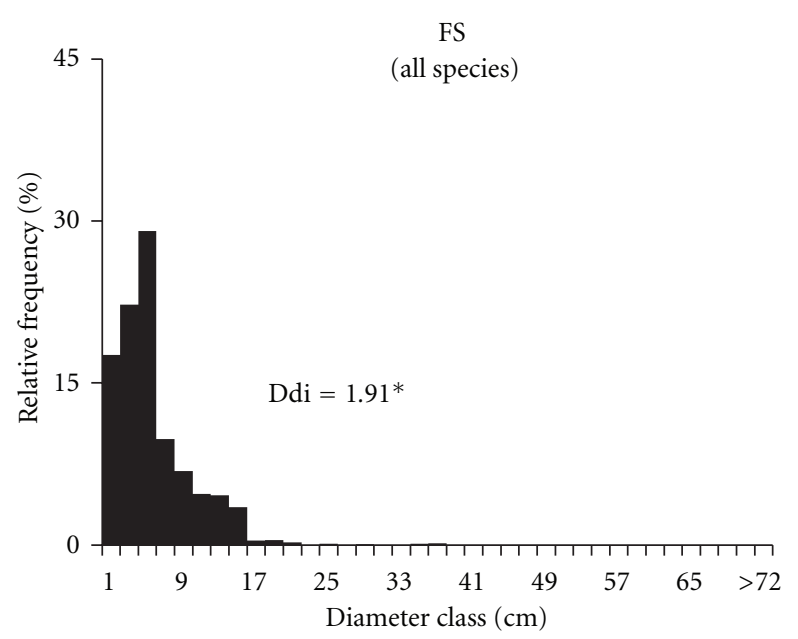

(a)

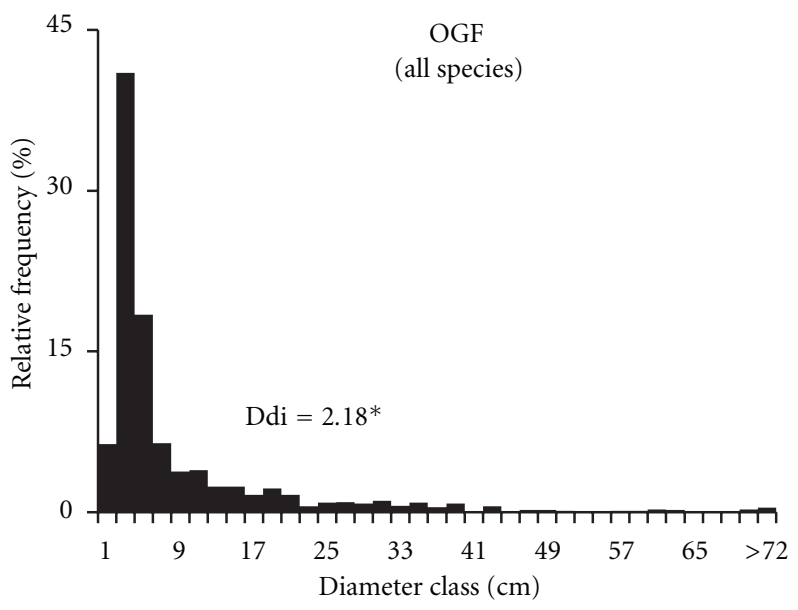

(c)

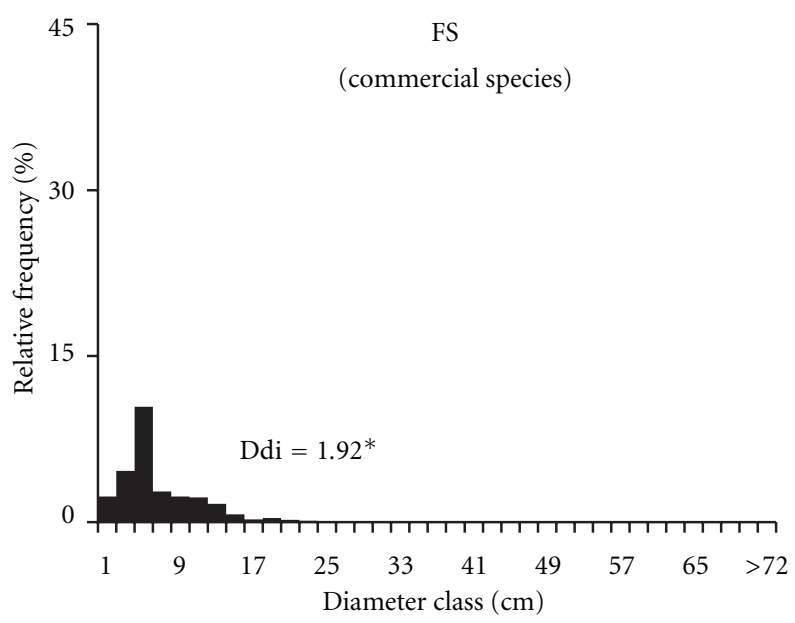

(b)

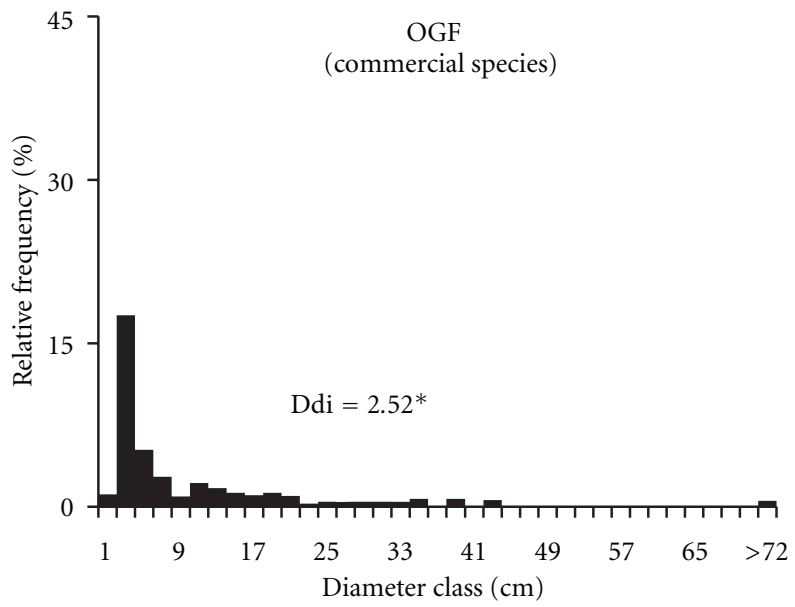

(d)

FIGURE 3: Stem diameter distribution and diameter diversity index (Ddi) of 32-year-old fallow stand (FS; a, b) and old-growth forest (OGF; c, d). Ddi was calculated based on the Shannon index, in which relative frequency of stems in diameter classes and number of diameter classes were used. The asterisk $(*)$ indicates significant difference of Ddi at $5 \%$ level by the $t$-test between FS and OGF. Only sapling and tree strata were included for calculation, for which the dbh data were available. The class width of $\mathrm{dbh}$ is $2 \mathrm{~cm}$.

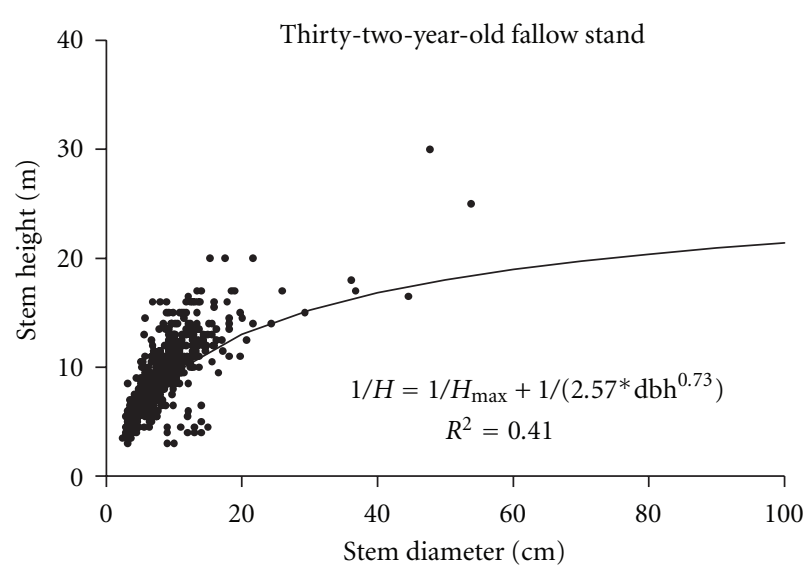

(a)

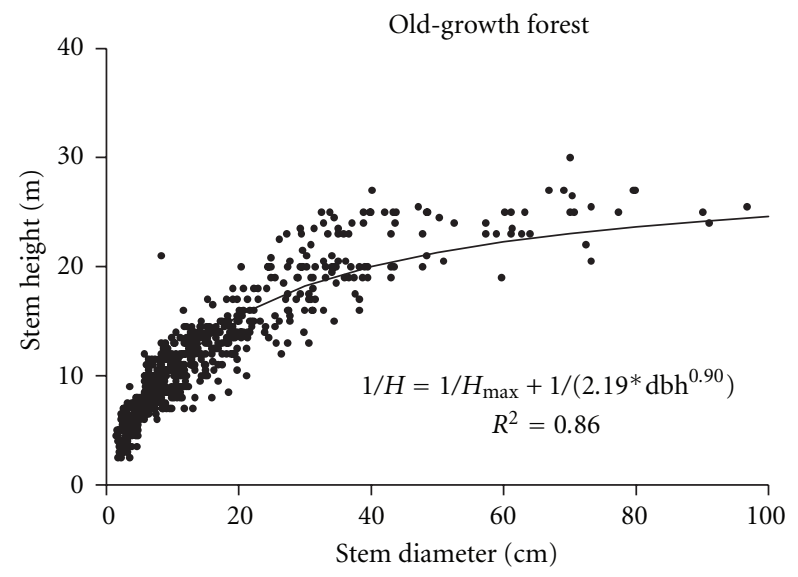

(b)

FIGURE 4: Relationships between stem height and stem diameter of FS stand (a) and OGF forest (b). Only the individuals in tree and sapling strata were included for calculation. The curves were fitted by using a $H_{\max }$ of 30 meters. 
TABle 3: List of species, families, commercially valuable species, and their traditional uses in 32-year-old fallow stand and in old-growth forest.

\begin{tabular}{|c|c|c|c|c|c|c|}
\hline \multirow{2}{*}{ Species } & \multirow{2}{*}{ Family } & \multirow{2}{*}{$\begin{array}{l}\text { Commercially } \\
\text { valuable species }\end{array}$} & \multicolumn{4}{|c|}{ Traditional uses } \\
\hline & & & Food & Medicine & Construction & Others \\
\hline Alniphyllum eberhardtii ${ }^{\mathrm{FS}}$ & Styracaceae & $*$ & & & $*$ & \\
\hline Betula alnoides ${ }^{\mathrm{FS}}$ & Betulaceae & $*$ & & Antiseptic & $*$ & \\
\hline Canarium album ${ }^{\mathrm{FS}}$ & Burseraceae & $*$ & $\mathrm{~F}$ & Antiseptic & $*$ & \\
\hline Canarium bengalensis ${ }^{\mathrm{FS}}$ & Burseraceae & $*$ & & $\begin{array}{l}\text { Antiseptic, } \\
\text { antithermal }\end{array}$ & $*$ & \\
\hline Castanopsis cerebrina ${ }^{\mathrm{FS}}$ & Fagaceae & $*$ & & & $*$ & \\
\hline Castanopsis sp. $1^{\mathrm{FS}}$ & Fagaceae & $*$ & & & & $\mathrm{Fu}$ \\
\hline Choerospodias axillaris ${ }^{\mathrm{FS}}$ & Anacardiaceae & $*$ & & Antiseptic & $*$ & \\
\hline Engelhardia roxburghiana ${ }^{\mathrm{FS}}$ & Juglandaceae & $*$ & & Antiseptic & $*$ & Po/fishing \\
\hline Lithocarpus ducampii ${ }^{\mathrm{FS}}$ & Fagaceae & $*$ & & & $*$ & \\
\hline Lithocarpus stenopus ${ }^{\mathrm{FS}}$ & Fagaceae & $*$ & & & $*$ & \\
\hline Schima wallichii ${ }^{\mathrm{FS}}$ & Theaceae & $*$ & & & $*$ & Fib/rope \\
\hline Syzygium jambos ${ }^{\mathrm{FS}}$ & Myrtaceae & $*$ & & $\begin{array}{l}\text { Antiseptic, } \\
\text { antithermal }\end{array}$ & $*$ & $\begin{array}{c}\text { Po/fishing } \\
\text { and } \\
\text { hunting }\end{array}$ \\
\hline Aporosa sphaerosperma ${ }^{\mathrm{FS}}$ & Euphorbiaceae & & & $\begin{array}{l}\text { Antiseptic, } \\
\text { antithermal }\end{array}$ & & \\
\hline Archidendron clypearia ${ }^{\mathrm{FS}}$ & Mimosaceae & & & Antiseptic & & \\
\hline Baccaurea ramiflora ${ }^{\mathrm{FS}}$ & Euphorbiaceae & & $\mathrm{F}$ & $\begin{array}{l}\text { Antiseptic, } \\
\text { antithermal }\end{array}$ & & \\
\hline Camellia tsaii ${ }^{\mathrm{FS}}$ & Theaceae & & & & & $\mathrm{Fu}$ \\
\hline Eriolaena candollei ${ }^{\mathrm{FS}}$ & Malvaceae & & & & & $\mathrm{Fu}$ \\
\hline Euodia lepta ${ }^{\mathrm{FS}}$ & Rutaceae & & & Antiseptic & & Po/fishing \\
\hline Eurya tonkinensis ${ }^{\mathrm{FS}}$ & Theaceae & & & & & $\mathrm{Fu}$ \\
\hline Ficus lacor ${ }^{\mathrm{FS}}$ & Moraceae & & & & & \\
\hline Garcinia multiflora $^{\mathrm{FS}}$ & Clusiaceae & & $\mathrm{F}, \mathrm{L}$ & Antioxidant & & \\
\hline Lindera sinensis ${ }^{\mathrm{FS}}$ & Lauraceae & & & & & $\mathrm{Fu}$ \\
\hline Litsea cubeba ${ }^{\mathrm{FS}}$ & Lauraceae & & & $\begin{array}{l}\text { Antiseptic, } \\
\text { antithermal }\end{array}$ & & \\
\hline Mallotus apelta ${ }^{\mathrm{FS}}$ & Euphorbiaceae & & & Antithermal & & Fib/rope \\
\hline Docynia indica ${ }^{\mathrm{FS}}$ & Rosaceae & & $\mathrm{F}$ & Antiseptic & & \\
\hline Premna flavescens ${ }^{\mathrm{FS}}$ & Verbenaceae & & & Antiseptic & & \\
\hline Psychotria rubra ${ }^{\mathrm{FS}}$ & Rubiaceae & & & Antiseptic & & \\
\hline Rhus javanica ${ }^{\mathrm{FS}}$ & Anacardiaceae & & & Antithermal & & \\
\hline Saurauia nepaulenis ${ }^{\mathrm{FS}}$ & Actinidiaceae & & $\mathrm{F}$ & $\begin{array}{l}\text { Antiseptic, } \\
\text { antithermal }\end{array}$ & & \\
\hline Styrax tonkinensis ${ }^{\mathrm{FS}}$ & Styracaceae & & & & $*$ & \\
\hline Wendlandia paniculata ${ }^{\mathrm{FS}}$ & Rubiaceae & & & & & \\
\hline Xylopia vielana ${ }^{\mathrm{FS}}$ & Annonaceae & & & & & \\
\hline Acer laurinum & Aceraceae & $*$ & & & & $\mathrm{O}$ \\
\hline Aglaia gigantea & Meliaceae & $*$ & & & & \\
\hline Alangium chinensis & Alangiaceae & $*$ & $\mathrm{~F}$ & & & \\
\hline Alseodaphne chinensis & Lauraceae & $*$ & & & $*$ & \\
\hline Amesiodendron chinense & Sapindaceae & $*$ & & & $*$ & \\
\hline
\end{tabular}


TABle 3: Continued.

\begin{tabular}{|c|c|c|c|c|c|c|}
\hline \multirow{2}{*}{ Species } & \multirow{2}{*}{ Family } & \multirow{2}{*}{$\begin{array}{l}\text { Commercially } \\
\text { valuable species }\end{array}$} & \multicolumn{4}{|c|}{ Traditional uses } \\
\hline & & & Food & Medicine & Construction & Others \\
\hline Castanopsis chinensis & Fagaceae & $*$ & S & & $*$ & \\
\hline Castanopsis ferox & Fagaceae & $*$ & & & & \\
\hline Castanopsis sp & Fagaceae & $*$ & & & $*$ & \\
\hline Castanopsis tonkinensis & Fagaceae & $*$ & S & & & \\
\hline Chisocheton paniculatus & Meliaceae & $*$ & & & & \\
\hline Cinnamomum curvifolium & Lauraceae & $*$ & & & & $\begin{array}{l}\text { Oi/indoor } \\
\text { fragrance }\end{array}$ \\
\hline Colona poilanei & Tiliaceae & $*$ & & & & Fib/rope \\
\hline Cryptocarya sp. & Lauraceae & $*$ & & & & \\
\hline Dalbergia balansae & Fabaceae & $*$ & & & $*$ & $\begin{array}{l}\text { Oi/indoor } \\
\text { fragrance }\end{array}$ \\
\hline Fokienia hodginsii & Cupressaceae & $*$ & & & * & $\mathrm{Ha}$ \\
\hline Garcinia fagracoides & Clusiaceae & $*$ & & & $*$ & \\
\hline Hydnocarpus anthelmintica & Flacourtiaceae & $*$ & & & & \\
\hline Lithocarpus echinophorus & Fagaceae & $*$ & & & * & \\
\hline Litsea glutinosa & Lauraceae & $*$ & & & & $\begin{array}{c}\text { Oi/ } \\
\text { indoor } \\
\text { fragrance }\end{array}$ \\
\hline Polyalthia jucunda & Annonaceae & $*$ & & & & \\
\hline Terminaria myriocarpa & Combrecaceae & $*$ & & & $*$ & \\
\hline Xylopia vielana & Annonaceae & $*$ & & & * & \\
\hline Acer laurinum & Aceraceae & & & & & \\
\hline Acronychia pedunculata & Rutaceae & & & & & \\
\hline Aglaia korthalsii & Meliaceae & & & & & \\
\hline Camelia japonica & Theaceae & & & & & $\mathrm{O}$ \\
\hline Eberhardtia tonkinensis & Sapotaceae & & $\mathrm{F}$ & & & \\
\hline Elaeocarpus griffithii & Elaeocarpaceae & & & & * & $\mathrm{Ta} /$ dyeing \\
\hline Euodia bodinieri & Rutaceae & & & & & \\
\hline Garcinia xanthochymus & Clusiaceae & & F, L & & & \\
\hline Gironniera subaequalis & Ulmaceae & & & & & \\
\hline Knema pierrei & Myristicaceae & & & & & \\
\hline Litsea lancifolia & Lauraceae & & & & & \\
\hline Madhuca hainanensis & Sapotaceae & & & & $*$ & $\begin{array}{l}\text { Oi/indoor } \\
\text { fragrance }\end{array}$ \\
\hline Neolitsea zeylanica & Lauraceae & & & & & \\
\hline Phellodendron amurense & Rutaceae & & & $\begin{array}{l}\text { Antiseptic, } \\
\text { antithermal }\end{array}$ & & \\
\hline Polyalthia cerasoides & Annonaceae & & $\mathrm{F}$ & & & \\
\hline Prunus arborea & Rosaceae & & & & * & \\
\hline Quercus bambusifolia & Fagaceae & & & & $*$ & \\
\hline Sterculia lanceolata & Sterculiaceae & & $\mathrm{F}$ & & & \\
\hline Symingtonia tonkinensis & Hamamelidaceae & & & & & \\
\hline Symplocos glomerata & Symplocaceae & & & & & \\
\hline Total in fallow stand & & 12 & 5 & 18 & 12 & 10 \\
\hline Total in old-growth forest & & 34 & 12 & 19 & 26 & 19 \\
\hline
\end{tabular}

Total number of species used were 30 and 56, while number of species used for multipurpose were 12 and 18 in fallow stand and in old-growth forest, respectively.

${ }^{\mathrm{FS}}$ Species appeared in fallow stand; F: edible fruits; L: edible leaves; S: edible seeds; O: ornamental; Fu: fuel; Fib: fiber; Oi: oil; Ta: tannin; Po: poison; Ha: handicraft. 
saplings of the pioneer species tended to be absent in OGF because of light deficiency on the forest floor. This pattern was not observed in FS, since recruitment into the sapling or tree strata always requires the seedlings to go through the seedling stage. In western Thailand, the number of seedling species in both OGF and 6-year-old fallow stands was only $30 \%$ of all tree species found. This may result from the limitation of seed rain and/or light deficiency in FS, since rotational shifting cultivation applied in that area resulted in high growth rate of vegetation in the first years after land abandonment [44].

Old-growth forest showed greater species diversity than FS both in terms of species number and the Shannon index. However, if variation of stem size class was also considered, there was no difference between OGF and FS in terms of species size-class diversity (Table 1). This means that individual distribution of all species in seedling, sapling, and tree strata was homogeneous in both OGF and FS.

Traditional uses of plants for medicinal purposes have been reported by many studies $[34,35,46]$. Among the 19 species of OGF that were used for medicine, eighteen were also present in FS (see the appendix), since most are pioneer species belonging to Anacardiaceae, Euphorbiaceae, Rubiaceae, and so on. [34, 35]. This is an advantage of FS in terms of economic value; however, extraction of the species for this traditional use affected the recovery process of FS. Only five of 12 edible species were represented in FS; this is probably due to seed rain limitation, since most of the edible species have large seeds with animal dispersion. Thirty of 32 species found in the FS were used for traditional purposes, indicating that the stems of those species tended to be recruited at the first stage of land abandonment. In the later stages of recovery, nontraditional use species are likely to be recruited in the FS. These species are commonly largeseeded, animal-dispersed, and shade-tolerant.

The real species number present in OGF and FS may be much higher than the number of species observed (Figure 1). Increasing survey areas will increase the number of species observed [47], and a specific ecosystem is likely to achieve this maximum richness asymptotically [40]. Meanwhile, percentage of overestimate of the species number tended to decrease with the increase in the number of samples (Figure 1). Therefore, a desired survey area should be determined, where such overestimate will be minimal.

\subsection{Characteristics of Forest Structure and Commercial Species} Recovery. Since a portion of fallow land in the present study area is being converted to timber producing forests, presence of commercially valuable species is an important indicator for evaluation of forest restoration. Forty-six percent of the species found in the old-growth forest (OGF) were commercially valuable, while it was $37.5 \%$ in the 32 -yearold fallow stand (FS). Proportion of the stems of commercial species was quite high (63.1\%) in OGF and much higher than that of FS (40.2\%) (Table 2). This is because most of the commercial species form the upper and main canopy layers in forests. They are also slow-growing species. The pattern was similar for the sapling stratum; however, the seedling density was much higher in OGF (Table 2). This is due to the limitation of seed rain in the FS, since most commercial species have large seed size and are animal-dispersed species $[34,35]$. The old-growth forest has high economic value in terms of wood production: $80.1 \%$ of total basal area belonged to the commercial species, and that was only $39.2 \%$ in FS. However, most commercial species grow slowly at first [43]. Recovery rate of basal area of the commercial species in the present study was $26.2 \%$, which was much higher than $19 \%$ of semideciduous forest in northwestern Laos [45], where selective logging in the surrounding OGF limited the seed rain of commercial species, leading to low ratio of stem density.

The patterns in frequency distribution of stem diameters were similar between OGF and FS for the pool of all species (Figures 3(a) and 3(c)) and for a group of commercial species (Figures 3(b) and 3(d)). This indicates that structure of the FS forest is similar to the stable stage of OGF. The difference of the diameter peaks may change from $4-6 \mathrm{~cm}$ class of FS to $2-4 \mathrm{~cm}$ class of OGF overtime, if sufficient seed rain continues for recruitment of the seedlings and saplings in FS. This may soon happen as a result of increasing number of animal dispersers in the older secondary forest [48]. The recovery of subtropical moist forest in Puerto Rico was faster than the present study; it took approximately 40 years for recovery of the structural characteristics similar to that of the OGF [28].

Even if stem numbers of saplings and trees are high, the values of stand basal area are mostly determined by the contribution of a small number of large individuals in both FS and OGF (Figure 2). This was also a conclusion of Tran et al. [8]. This pattern is typical of any OGF, where its biomass is dominated by some upper canopy individuals. This phenomenon is not generally seen in young-regenerated forests, where the size of individuals is much more homogenous. However in the present study, slow accumulation of basal area with rapid stem recruitment occurring concurrently in FS resulted from contribution of basal area of some very large-sized individuals, which had not been cut when local people practiced shifting cultivation. The recovery rate of the basal area in the present study was lower than those of previous studies in tropical dry forest $[7,16]$ and in mix-deciduous forest [45].

Vertical structure (canopy height) of OGF was different from that of FS. Canopy of OGF included an upper layer of trees taller than $20 \mathrm{~m}$ (Figure 4(b)), which contributed most for the basal area. Meanwhile, canopy structure of FS was simpler and lacking the uppermost layer (Figure 4(a)). This is not surprising, since tropical tree species often require a long time (50 years to more than 100 years) to become mature. However, a very dry tropical deciduous forest in southern Mexico required only 13 years for recovering $75 \%$ of canopy height of OGF [7]. In most other comparisons, tropical dry forest is more resilient in canopy height development than tropical rain forest [7], except for one example [49] where a tropical rain forest grew on a nutrient rich soil.

4.3. Management Implications. The complexity of forest recovery after shifting cultivation that has been observed in 
various forest types, disturbance regimes, climate conditions, and so forth challenge restoration ecologists. Appropriate restoration strategy should be sought by considering this complexity. Requirements on the rate of recovery and the similarity in species composition to the surrounding oldgrowth forest are most important considerations. If relying only on natural regeneration, the fallow stand in the present study may require 45 years for its stem density to return to the condition of OGF, 60 years for its basal area, and 70 years for its species diversity. It may require an even longer time for a group of commercially valuable species to reach abundance similar to that of OGF, especially in terms of basal area. Adding stems of commercial species by artificial seeding and/or planting may be an effective way to shorten the recovery process. Low ratio of seedlings (37.3\%) and saplings $(23.2 \%)$ of commercial species in FS may have resulted from their competition with seedlings of non-commercial species. Therefore, silvicultural treatments such as thinning and forest floor clearing may be necessary. However, the approach of stem addition and/or other silvicultural operations may not be applicable to a large area since it is costly to apply labor intensive techniques, compared to the approach of natural regeneration. Therefore, remnant trees of commercial species may be used as the seed source for natural regeneration in the fallow stand in the present study area. Then, it is also necessary to consider the trade-off of low crop production due to shading by crowns of other adult trees.

\section{Appendix}

For more details see Table 3.

\section{Acknowledgments}

The authors thank researchers of Chiềng Bôm Research Station of Forest Science Institute of Vietnam for their help during fieldwork and other assistance from Northwestern University of Vietnam, and anonymous reviewers for commenting on the paper. This paper was supported by a grants-in-aid for scientific research (no. D/4602-1) from International Foundation for Science.

\section{References}

[1] O. Mertz, L. Reed, U. N. Wadley et al., "A fresh look at shifting cultivation: fallow length an uncertain indicator of productivity," Agricultural Systems, vol. 96, no. 1-3, pp. 75-84, 2008.

[2] A. Angelsen, "Shifting cultivation and "deforestation": a study from Indonesia," World Development, vol. 23, no. 10, pp. 17131729, 1995.

[3] FAO, State of the World's Forests, Food and Agriculture Organization of the United Nations, 2005.

[4] D. S. Do, Shifting Cultivation in Vietnam: Its Social, Economic and Environmental Values Relative to Alternative Land Use, IIED Forestry and Land Use Series, London, Uk, 1994.

[5] D. Lawrence, "Biomass accumulation after 10-200 years of shifting cultivation in Bornean rain forest," Ecology, vol. 86, no. 1, pp. 26-33, 2005.
[6] A. E. Lugo, F. N. Scatena, W. Silver, C. S. Molina, and P. G. Murphy, "Resilience of tropical wet and dry forests in Puerto Rico," in Resilience and the Behavior of Large-Scale Systems, L. H. Gunderson and L. Pritchard Jr., Eds., pp. 195-225, Island Press, Washington, DC, USA, 2002.

[7] E. Lebrija-Trejos, F. Bongers, E. A. Pérez-García, and J. A. Meave, "Successional change and resilience of a very dry tropical deciduous forest following shifting agriculture," Biotropica, vol. 40, no. 4, pp. 422-431, 2008.

[8] Tran Van Do, A. Osawa, and N. T. Thang, "Recovery process of a mountain forest after shifting cultivation in Northwestern Vietnam," Forest Ecology and Management, vol. 259, no. 8, pp. 1650-1659, 2010.

[9] M. R. Guariguata and R. Ostertag, "Neotropical secondary forest succession: changes in structural and functional characteristics," Forest Ecology and Management, vol. 148, no. 1-3, pp. 185-206, 2001.

[10] R. L. Chazdon, "Chance and determinism in tropical forest succession," in Tropical Forest Community Ecology, W. P. Carson and S. A. Schnitzer, Eds., pp. 384-408, Blackwell Publishing, Oxford, UK, 2008.

[11] D. L. M. Vieira and A. Scariot, "Principles of natural regeneration of tropical dry forests for restoration," Restoration Ecology, vol. 14, no. 1, pp. 11-20, 2006.

[12] P. M. Fearnside and W. M. Guimarães, "Carbon uptake by secondary forests in Brazilian Amazonia," Forest Ecology and Management, vol. 80, no. 1-3, pp. 35-46, 1996.

[13] S. Brown and A. E. Lugo, "Tropical secondary forests," Journal of Tropical Ecology, vol. 6, no. 1, pp. 1-32, 1990.

[14] B. Finegan, "Pattern and process in neotropical secondary rain forests: the first 100 years of succession," Trends in Ecology and Evolution, vol. 11, no. 3, pp. 119-124, 1996.

[15] M. Fukushima, M. Kanzaki, M. Hara, T. Ohkubo, P. Preechapanya, and C. Choocharoen, "Secondary forest succession after the cessation of swidden cultivation in the montane forest area in Northern Thailand," Forest Ecology and Management, vol. 255, no. 5-6, pp. 1994-2006, 2008.

[16] D. K. Kennard, "Secondary forest succession in a tropical dry forest: patterns of development across a 50-year chronosequence in lowland Bolivia," Journal of Tropical Ecology, vol. 18, no. 1, pp. 53-66, 2002.

[17] X. Zou, C. P. Zucca, R. B. Waide, and W. H. McDowell, "Longterm influence of deforestation on tree species composition and litter dynamics of a tropical rain forest in Puerto Rico," Forest Ecology and Management, vol. 78, no. 1-3, pp. 147-157, 1995.

[18] M. Fukushima, M. Kanzaki, M. T. Hla, and M. Yazar, "Recovery process of fallow vegetation in the traditional Karen Swidden cultivation system in the Bago mountain range, Myanmar," Southeast Asian Studies, vol. 45, no. 3, pp. 317-333, 2007.

[19] C. Gehring, M. Denich, and P. L. G. Vlek, "Resilience of secondary forest regrowth after slash-and-burn agriculture in central Amazonia," Journal of Tropical Ecology, vol. 21, no. 5, pp. 519-527, 2005.

[20] D. N. Fernandes and R. L. Sanford, "Effects of recent land-use practices on soil nutrients and succession under tropical wet forest in Costa Rica," Conservation Biology, vol. 9, no. 4, pp. 915-922, 1995.

[21] R. C. G. Mesquita, K. Ickes, G. Ganade, and G. B. Williamson, "Alternative successional pathways in the Amazon Basin," Journal of Ecology, vol. 89, no. 4, pp. 528-537, 2001.

[22] N. Ramírez-Marcial, M. González-Espinosa, and G. WilliamsLinera, "Anthropogenic disturbance and tree diversity in 
Montane rain forests in Chiapas, Mexico," Forest Ecology and Management, vol. 154, no. 1-2, pp. 311-326, 2001.

[23] S. Fujisaka, G. Escobar, and E. J. Veneklaas, "Weedy fields and forests: interactions between land use and the composition of plant communities in the Peruvian Amazon," Agriculture, Ecosystems and Environment, vol. 78, no. 2, pp. 175-186, 2000.

[24] D. Lawrence, "Erosion of tree diversity during 200 years of shifting cultivation in Bornean rain forest," Ecological Applications, vol. 14, no. 6, pp. 1855-1869, 2004.

[25] E. Hooper, P. Legendre, and R. Condit, "Barriers to forest regeneration of deforested and abandoned land in Panama," Journal of Applied Ecology, vol. 42, no. 6, pp. 1165-1174, 2005.

[26] C. O. Delang, "Ecological succession of usable plants in an eleven-year fallow cycle in Northern Lao P. D. R," Ethnobotany Research and Applications, vol. 5, pp. 331-350, 2007.

[27] N. T. Pham, Research on characteristics of secondary forest succession following shifting cultivation in Thai Nguyen and BacKan Provinces to recommend silvicultural technical methods for promoting natural regeneration process, $\mathrm{PhD}$ Dissertation, Forest Science Institute of Vietnam, 2003.

[28] T. M. Aide, J. K. Zimmerman, J. B. Pascarella, L. Rivera, and H. Marcano-Vega, "Forest regeneration in a chronosequence of tropical abandoned pastures: implications for restoration ecology," Restoration Ecology, vol. 8, no. 4, pp. 328-338, 2000.

[29] V. T. Thai, Forest Flora in Vietnam, Science and Technology Publishing House, Hanoi, Vietnam, 1978.

[30] V. D. Tran, L. K. Don, and V. T. Hoang, "Rehabilitation of the native forest tree species at the forest plantations and denuded hills of Namlau commune in Sonla Province, Vietnam," Forest Science and Technology, vol. 1, no. 1, pp. 51-58, 2005.

[31] N. B. Nguyen, Forest Soil of Vietnam, Agriculture Publishing House, Hanoi, Vietnam, 1996.

[32] Q.T. Bui, Some problems on slash-and-burn cultivation soil in Northwestern region of Vietnam and the direction of its utilization, PhD Dissertation, Hanoi, Vietnam, 1990.

[33] H. Conklin, Hanunoo Agriculture: A Report on an Integral System of Shifting Cultivation in the Philippines, Food and Agriculture Organization of the United Nations, 1957.

[34] M. C. Le and T. H. Le, Forest Trees of Vietnam, Agriculture Publishing House, Hanoi, Vietnam, 2000.

[35] H. Tran, Forest Tree Resources of Vietnam, Agriculture Publishing House, TP Ho Chi Minh, Vietnam, 2002.

[36] Forestry Ministry of Vietnam, Table of timber durability/ durability classes, Hanoi, 1977.

[37] A. E. Magurran, Ecological Diversity and Its Measurement, Princeton University Press, Princeton, NJ, USA, 1988.

[38] A. Chao, "Estimating the population size for capturerecapture data with unequal catchability," Biometrics, vol. 43, no. 4, pp. 783-791, 1987.

[39] R. K. Colwell and J. A. Coddington, "Estimating terrestrial biodiversity through extrapolation," Philosophical Transactions of the Royal Society of London Series B, vol. 345, no. 1311, pp. 101-118, 1994.

[40] R. K. Colwell, X. M. Chang, and J. Chang, "Interpolating, extrapolating, and comparing incidence-based species accumulation curves," Ecology, vol. 85, no. 10, pp. 2717-2727, 2004.

[41] J. Weiner and O. T. Solbrig, "The meaning and measurement of size hierarchies in plant populations," Oecologia, vol. 61, no. 3, pp. 334-336, 1984.

[42] H. Ogawa, "An attempt at classifying forest types based on the tree height-DBH relationship," in Interim Report of Japan International Biological Programme, T. Kira, Ed., pp. 3-17, ICSU, Japan International Biological Programme, 1969.
[43] Tran Van Do, A. Osawa, T. T. Nguyen et al., "Population changes of early successional forest species after shifting cultivation in Northwestern Vietnam," New Forests, vol. 41, no. 2, pp. 247-262, 2011.

[44] P. Wangpakapattanawong, N. Kavinchan, C. Vaidhayakarn, D. Schmidt-Vogt, and S. Elliott, "Fallow to forest: applying indigenous and scientific knowledge of swidden cultivation to tropical forest restoration," Forest Ecology and Management, vol. 260, no. 8, pp. 1399-1406, 2010.

[45] Sovu, M. Tigabu, P. Savadogo, P. C. Odén, and L. Xayvongsa, "Recovery of secondary forests on swidden cultivation fallows in Laos," Forest Ecology and Management, vol. 258, no. 12, pp. 2666-2675, 2009.

[46] H. H. Pham, An Illustrated Flora of Vietnam, Young Publishing House, Hanoi, Vietnam, 1999.

[47] S. M. Scheiner, "Six types of species-area curves," Global Ecology and Biogeography, vol. 12, no. 6, pp. 441-447, 2003.

[48] J. A. Grieser, Timber Production and Biodiversity Conservation in Tropical Rain Forests, Cambridge University Press, Cambridge, UK, 1997.

[49] E. F. Moran, E. S. Brondizio, J. M. Tucker, M. C. da SilvaForsberg, S. McCracken, and I. Falesi, "Effects of soil fertility and land-use on forest succession in Amazônia," Forest Ecology and Management, vol. 139, no. 1-3, pp. 93-108, 2000. 

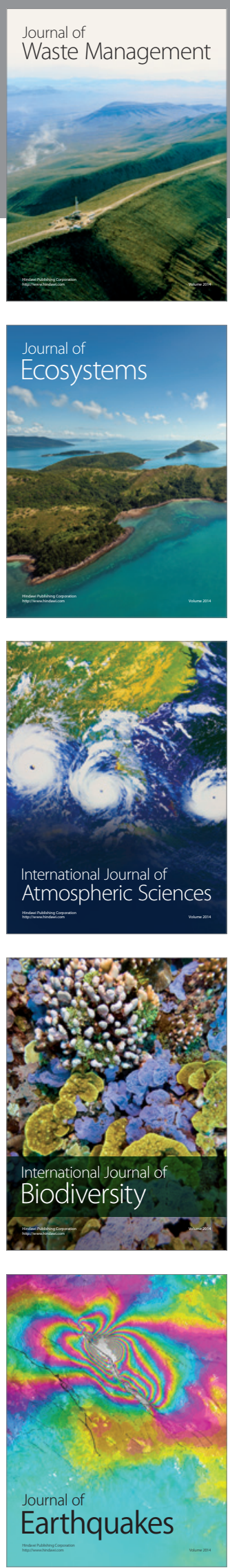
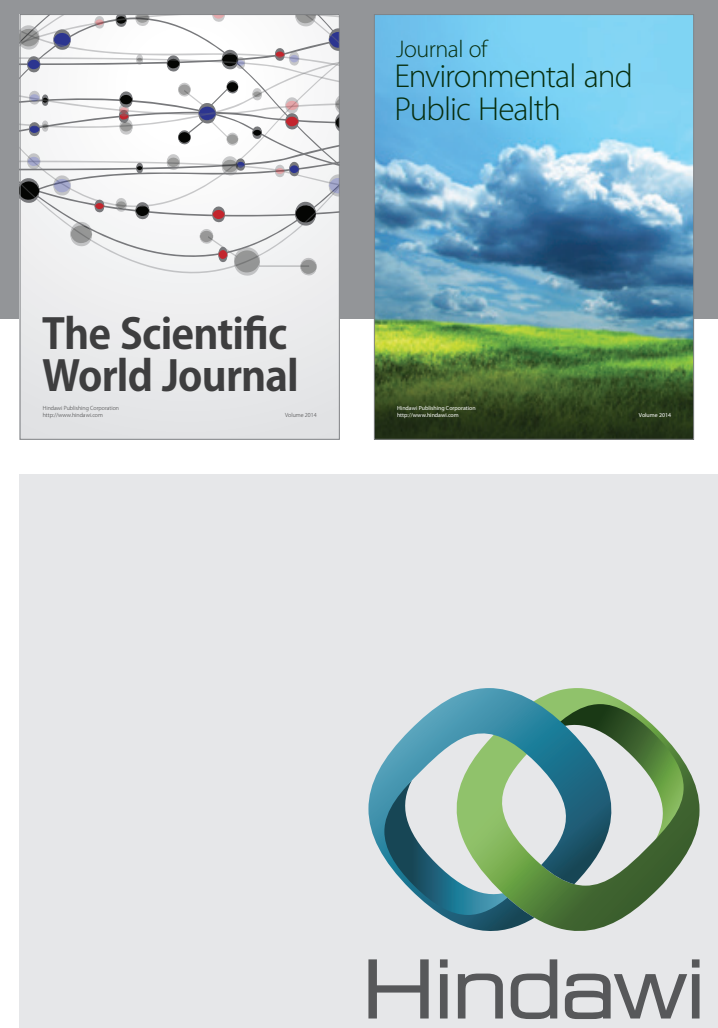

Submit your manuscripts at

http://www.hindawi.com
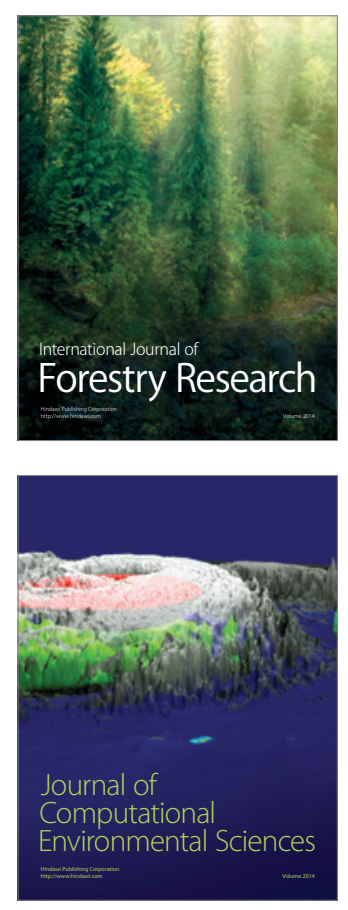
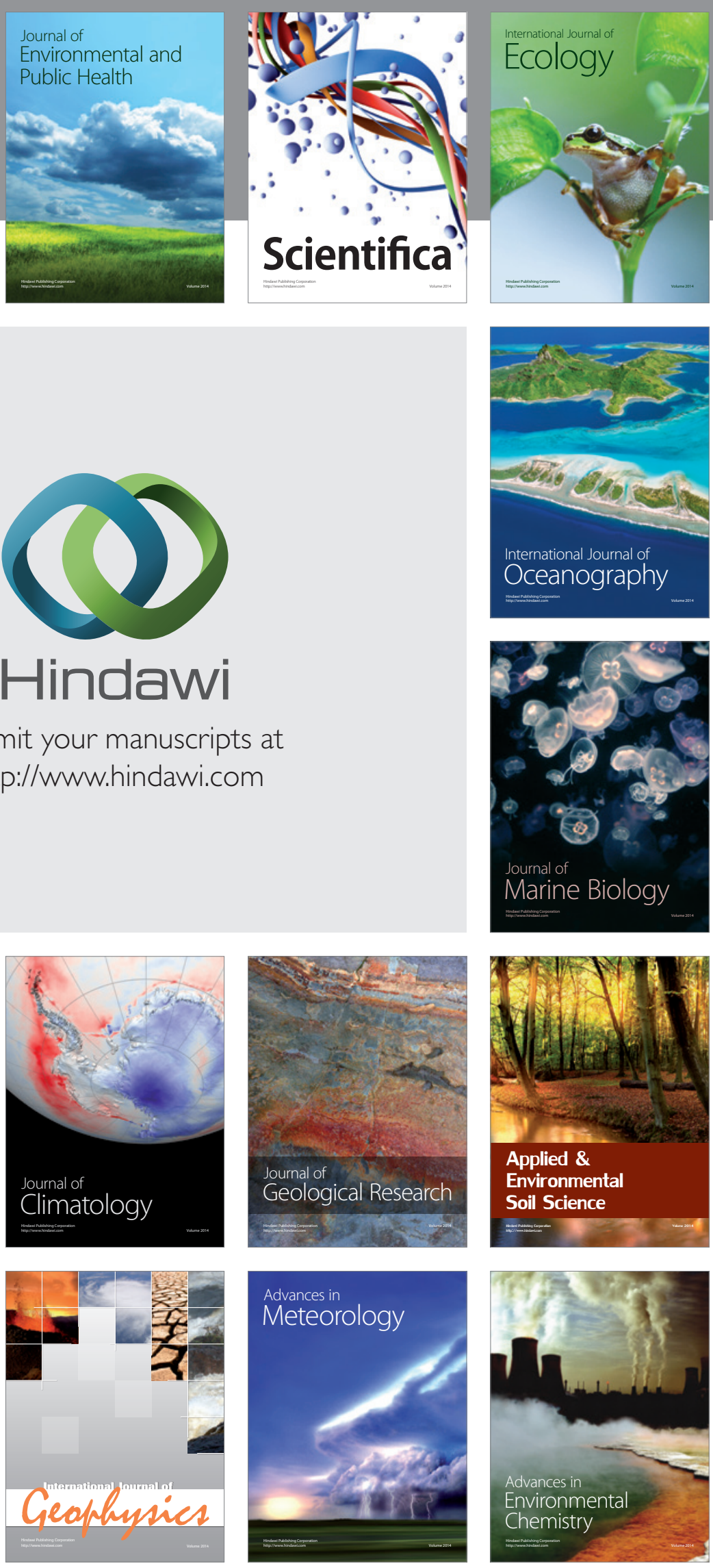